\title{
Pembelajaran Aransemen Musik Berbasis Teknologi Komputer di Jurusan Musik FSP Institut Seni Indonesia Yogyakarta
}

\author{
Tri Wahyu Widodo \\ Program Studi Pendidikan Musik, Jurusan Musik FSP ISI Yogyakarta; +628122943657
}

\begin{abstract}
Computer technology with its complex algorithms system made for a wide range benefits to support the efficiency of time and material of human labor. Because of that reason it has given a great contribution to the problem solving of human as its user, which commonly called the brain-ware. Learning process is a human activity which is practiced on a daily basis. Various written and auditory obstacles faced by teachers and students. In music teaching, for example, a teacher gives examples by playing a musical instrument or through vocal practice. This activity is an example of manually teaching process that of course having some limitations. The purpose of this study is to provide an alternative in learning process that has interactive values. Computer technology will be contributed to make the learning process to be easier then mconventional way, for example, arranging or composing a piece of music in a form of large or small groups without requiring a huge cost. In order to fulfill musical creativity needs, current computer technology has been developing an intelligent electronic devices that can help users to access music menu application program by easily pressing buttons. Computer technology comprises unseparated parts of hardware and software due to their interrelated functions. The first as an electronic media while the second as a system for an operator person to command the computer in order to achieve his needs. This research has resulted an alternative formula in music learning-teaching process by using computer technology, especially for several applied subjects such as arranging music and others theoretical subjects, for example music theory, harmony, counterpoint, and composition.
\end{abstract}

Keywords: computers, music, musical arrangements

\begin{abstract}
Abstrak
Tekonologi komputer dibuat oleh manusia difungsikan untuk memberikan berbagai macam manfaat. Salah satu manfaat teknologi komputer yaitu mendukung kerja manusia agar lebih efisien baik dari waktu maupun materi. Teknologi komputer diciptakan menggunakan sistem algoritma yang komplek. Sistem matematis yang komplek dibuat agar dapat mudah digunakan untuk memecahkan permasalahan yang dihadapi oleh manusia sebagai user atau biasa disebut dengan brainware. Proses pembelajaran merupakan kegiatan yang setiap hari dilakukan oleh manusia. Berbagai kendala baik secara tulisan maupun auditif sering dilalui oeh seorang pengajar maupun bagi para peserta ajar. Seperti proses pembelajaran musik, seorang pengajar memberikan contoh-contoh sering dijumpai dengan memainkan alat musik atau melalui praktek vokal. Contoh-contoh tersebut merupakan kegiatan belajar mengajar secara manual sehingga terdapat keterbatasan-keterbatasan baik dari sisi pengajar maupun peserta ajar. Tujuan penelitian ini adalah memberikan alternatif lain dari proses belajar mengajar yang memiliki nilai-nilai interaktiv. Melalui teknologi komputer dapat membantu dalam proses belajar mengajar membuat sebuah karya musik dengan cara mengarangsemen atau menggubah karya musik dalam bentuk kelompok kecil atau pun besar tanpa membutuhkan biaya yang besar. Teknologi komputer sudah dikembangkan menjadi alat elektronik yang cerdas, sehingga user dapat memfungsikan tombol-tombol ataupun menu-menu program aplikasi musik untuk kebutuhan mengembangkan kreativitas musik lebih mudah. Teknologi komputer tergai atas perangkat keras dan perangkat lunak. Kedua bagian tersebut tidak dapat dipisahkan, karena bagian perangkat keras sebagai media elektronik dan perangkat lunak sebagai bagian untuk menjalankan perintah-perintah dari komputer itu sendiri atau dari perintah-perintah manusia pada perangkat keras. Hasil yang akan dicapai dalam penelitian ini dapat memberikan sebuah alternatif dalam proses belajar mengajar musik
\end{abstract}


menggunakan teknologi komputer, khususnya pada matakuliah musik yang bersifat teoritis khususnya membuat aransemen musik. Teknologi komputer juga dapat dimanfaatkan seperti pada matakuliah teori musik, harmoni, kontrapunk, komposisi musik, dan masih banyak lagi.

Kata Kunci: komputer, musik, aransemen musik

\section{Pendahuluan}

\section{Latar Belakang}

Era globalisasi dibidang pendidikan tidak dapat dibendung dengan idealisme manual. Manusia selalu berkembang untuk mencari sesuatu capaian dengan praktis, cepat dan mudah. Pencapaian tujuan praktis, cepat, dan mudah secara teknis telah dijawab dengan perkembangan teknologi. Teknologi tersebut saat sekarang ini adalah teknologi komputer yang memiliki kemampuan bahasa digital tingkat tinggi. Walaupun teknologi manual saat ini masih terus digunakan dan teknologi komputasi sebagai pelengkap dari kelemahan teknologi manual.

Sesuai perkembangan teknologi yang semakin pesat, maka sumber daya manusia sangat dituntut untuk good scale disegala bidang. Good scale dalam bidang pendidikan pun akan terbantu dengan teknologi komputer. Teknologi komputer bukan lagi sebagai fasilitas langka untuk dimanfaatkan dalam bidang pendidikan. Teknologi komputer sangat membantu sumber daya manusia untuk menyelesaikan tugas-tugas yang diemban. Apa pun pekerjaan baik untuk pribadi, kelompok maupun institusi. Teknologi komputer bukan lah sebagai fasilitas pembodohan atau membuat sumber daya manusia malas, tetapi teknologi tersebut memiliki fungsi meringankan tugas dan memiliki kepraktisan.

Proses belajar mengajar untuk saat ini tidak lah sulit dan membosankan. Proses belajar mengajar dapat dilakukan dengan media teknologi komputer akan mem- berikan suasana balajar mengajar lebih interaktif dan menarik. Berbagai macam program aplikasi komputer untuk pendidikan dibuat menarik dan mudah digunakan untuk proses belajar mengajar, baik dari pendidikan ilmu pengetahuan alam hingga ilmu seni. Sebagai contoh, program komputer untuk presentasi, yaitu Power Point, program komputer untuk pengolah bahasa, yaitu Microssoft Words, dan salah satu dari berbagai macam program komputer untuk musik, khususnya untuk menulis notasi, aransemen maupun komposisi, yaitu antara lain Sibelius. Adapun program komputer untuk musik terbagi atas beberapa bagian yaitu program komputer untuk perekaman bunyi, iringan musik, program interaktif untuk pembelajaran musik.

Teknologi komputer untuk musik masih kurang banyak digunakan ataupun sebagain besar pembelajaran musik masih secara manual. Sekolah atau institusiinstitusi pendidikan formal maupun non formal tertentu saja yang menggunakan fasilitas ini; karena untuk investasi perangkat keras, masih dirasakan mahal. Faktor lain adalah sumber daya manusia pendidik, yang kurang dan belum mengenal program komputer musik yang difungsikan pada perangkat teknologi komputer, karena ketidaktahuan. Disamping itu literaturliteratur teknologi komputer khusus untuk musik masih jarang. Oleh karena itu, ekplorasi pengetahuan program-program aplikasi komputer untuk musik, seperti program komputer musik Sibelius sangat diperlukan. Hal ini dapat menambah pengetahuan dan kekayaan literatur bagi 
pengajar maupun siswa, atau pun di masyarakat baik kelompok maupun personal.

Pembahasan dalam penelitian ini didasarkan atas tiga rumusan masalah yaitu:

a. Bagaimana proses menggunakan fasilitas teknologi komputer untuk aransemen musik?

b. Apakah teknologi komputer dapat membantu untuk aransemen musik?

c. Bagaimana menggunakan teknologi komputer untuk membuat aransemen musik melalui program penulisan notasi yang memberikan fasilitas teknis yang tidak dapat dilakukan secara manual?

Sumber dalam bentuk buku, literatur, hasil seminar atau pun penelitian di dalam negeri tentang program komputer sebagai media untuk belajar aransemen musik sampai saat ini belum ada. Pelacakan penggunaan teknologi komputer di berbagai institusi formal mau pun informal memakai program komputer untuk balajar aransemen musik juga belum ada. Oleh karena itu penelitian ini bersifat baru.

Seiring perkembangan budaya dan teknologi, proses belajar mengajar pun berkembang. Proses belajar mengajar musik yang didasarkan secara monoton menjadi lebih interaktif dan komunikatif, karena proses belajar melalui media teknologi komputer dengan learn by doing. Hal ini sangat penting untuk dilakukan, karena belajar seni musik tidak hanya belajar secara koniktif, tetapi motorik serta afektif.

Pembelajaran yang berkaitan dengan teknologi tentu dapat diukur antara lain dengan melalui unjuk kerja dalam hal: pemahaman (understanding), menguasai teori, kemampuan analitis,dan pemecahan masalah, ketrampilan menggunakan alat serta memahami prosedur kerja rutin, kemampuan meneliti sumber daya alam, dan kemampuan berkomunikasi (Supeno Djanali: 2005). Ilmu sosial termasuk musik tidak lepas dari pemikiran Supeno Djanali. Melalui teknologi komputasi siswa akan dapat memahami, menguasai hingga terampil dalam menggunakan teknologi komputer untuk aransemen musik.

Pada Paradigma Baru Pendidikan Tinggi Seni di Indonesia (2005) juga menunjukkan bahwa proses pembelajaran harus inovatif dan mengikuti perkembangan teknologi terkini, yakni menggunakan sistem CAL (Computer Aided Learning). Hal ini dimaksudkan bahwa memanfaatkan komputer dan perangkat lunak yang didesain untuk membantuproses pembelajaran.

Seorang calon musisi dibutuhkan sumber bunyi untuk mendapatkan suatu karya seni musik. Melalui teknologi komputasi Peter Meanning (1993) dalam buku Electronic and Computer Music memaparkan bahwa teknologi komputasi yang saat ini memiliki kecerdasan buatan yang baik, maka tidak sulit untuk mewujudkan bunyi yang mirip dengan aslinya.

Aransemen musik menggunakan fasilitas teknologi digital dengan perangkat elektronik komputer sangat membantu sangat membantu. Melalui teknologi komputasi dengan menggunakan program musik komputer seperti Sibelius. Teknologi komputer yang menggunakan program musik komputer merupakan salah satu media dan proses pembelajaran musik melalui teknologi komputer memberikan kontribusi strategi dalam kegiatan belajar mengajar musik.

2. Tujuan dan Manfaat Penelitian

a. Tujuan Penelitian:

1) Untuk membangun proses belajar mengajar menggunakan metode- 
metode yang lebih interaktif dengan menggunakan fasilitas teknologi komputer digital sesuai perkembangan teknologi terkini.

2) Untuk membuktikan bahwa menggunakan teknologi komputasi tidak sesulit yang dibayangkan. Melalui penelitian teknologi komputasi untuk pembelajaran aransemen membantu dalam kemudahan menuangkan ide-ide kreatif musikal dan membantu dalam mewujudkan imaginasi karya musik dalam bentuk bunyi tanpa harus mengeluarkan biaya dan tenaga yang banyak.

3) Untuk menambah wawasan dan pengetahuan menggunaan teknologi komputer, khususnya dalam belajar mengajar musik.

\section{b. Kontribusi Penelitian:}

1) Untuk memberikan kontribusi pada inovasi belajar mengajar, seperti teori musik, harmoni, aransemen musik maupun orkestrasi musik.

2) Untuk memperkaya dan mempertajam pengetahuan teknologi komputer khusus musik bagi peneliti sendiri.

3) Untuk menambah bahan ajar atau referensi ilmiah pada proses pembelajaran Mata Kuliah Aplikasi Komputer Musik di Jurusan Musik Fakultas Seni Pertunjukan ISI Yogyakarta.

4) Untuk memberikan kontribusi bagi pengajar maupun mahasiswa dalam proses belajar mengajar di semua Minat Utama pada Program Studi Seni Musik dan semua program studi yang berkaitan dengan ilmu musik barat di lingkungan Jurusan Musik Fakultas Seni Pertunjukan ISI Yogyakarta.

5) Untuk memberikan petunjuk tentang penggunaan program aplikasi komputer Sibelius untuk aktifitas bermusik, baik untuk civitas mau pun di luar civitas.

6) Untuk memperkaya kepustakaan di lingkungan ISI Yogyakarta.

2. Metode Penelitian

Penelitian pembelajaran aransemen musik berbasis teknologi komputer di Jurusan Musik FSP ISI Yogyakarta dilakukan dengan metode deskriptif dengan analisis dari studi kasus pada partisipasipan. Pemilihan metode ini dipilih, karena metode deskriptif analisis studi kasus yang dilakukan dengan cara mendeskriptifkan fakta-fakta proses pembelajaran teknologi kumputer yang menggunakan program musik komputer untuk aransemen dan kemudian dilanjutkan dengan analisis. Pendekatan yang menggabungkan konsep, teori-teori dari berbagai ilmu-ilmu disiplin lain memberikan keluasan dalam meneliti. Pendekatan ini merupakan pendekatan secara multi-disiplin. Pendekatan multidisiplin tidak hanya pada analisis tetapi juga dalam memperoleh dan pengumpulan datanya. Dengan metode penelitian ini memberikan gambaran secara lebih jauh peran teknologi komputer sebagai media belajar aransemen musik. Untuk memperoleh data yang akurat pada penelitian ini, maka dilakukan penggalian informasi, praktek menggunakan teknologi komputer, dan mencatat proses kreatif dari siswa kelas pada mata kuliah Aplikasi Komputer. Peran teknologi komputer dalam membantu mengolah aransemen musik oleh 
siswa merupakan sebuah sebuah studi kasus melalui penggalian data secara langsung. Tahapan ini peneliti menggali melalui aktivitas siswa kelas dalam membuat aransemen musik memalui teknologi komputer. Aktivitas siswa kelas mata kuliah aplikasi komputer dalam menggunakan teknologi komputer memerlukan pemahaman literatur atau pustaka. Penguatan pemahaman studi pustaka menjadi penting dalam penelitian ini. Pencatatan proses pembelajaran aransemen menulis musik menggunakan program musik komputer dengan cara mewawancarai dan mengamati partisipan merupakan sebuah bagian faktor yang sangat penting dalam penelitian ini. Hal ini untuk mengetahui konsep musikologis yang digunakan dalam proses interaksi dari pengguna komputer dengan teknologi komputer.

Wawancara dalam penelitian menjadi sumber lisan yang kebanyakan dicari dan dikumpulkan oleh peneliti melalui sebuah aktivitas penelitian lapangan, karena obyek penelitian masih hidup. Penelitian ini juga menggunakan metode penelitian lapangan. Hal ini dimaksudkan yaitu melakukan pengamatan yang cermat di lapangan. Pengamatan ini disebut dengan observasi. Peneliti aktif melakukan pengamatan aktivitas siswa kelas dalam membuat aransemen musik menggunakan teknologi komputer. Observasi aktif yang menempatkan peneliti sebagai warga sementara dari pemilik seni itu, berarti peneliti menjadi insider atau 'orang dalam'. Observasi semacam inilah yang disebut dengan participant observation, dan penelitinya disebut sebagai participant observer.

Sumber tertulis melalui sebuah studi pustaka dilakukan dalam penelitian ini bertujuan untuk mendukung dan menambah referensi. Peneliti mengambil sumber-sumber terulis dari buku, jurnal, ensiklopedi, dan kamus, serta sumbersumber lain seperti media internet.

Pendekatan musikologis melalui mengamati proses interaksi siswa kelas melalui teknologi komputer dalam membuat aransemen musik yang berfungsi untuk membatasi dalam penelitian ini. Penelitian ini dilakukan terdiri dari beberapa tahapan, antara lain: pengumpulan data melalui studi pustaka, observasi lapangan, wawancara kepada nara sumber, pengolahan data, dan tahapan analisis data. Kemudian urutan kegiatan yang dilakukan penelitian ini diawali dengan kegiatan observasi awal tentang topik teliti; kemudian pengkajian topik penelitian melalui kepustakaan untuk mencari referensi yang berkaitan dengan topik; melakukan penelitian lapangan untuk mencari data yang akurat melalui wawancara siswa kelas sebagai nara sumber, melakukan dokumentasi lapangan dengan cara merekam secara audio maupun visual. Setelah data terkumpul, selanjutnya data dipilih, disusun, diolah, dan diseleksi untuk mencari data yang lebih relevan serta berkaitan dengan topik penelitian.

Penelitian yang akan dilakukan melalui aplikasi dan eksploratif dengan menekankan aspek kreatifitas. Metode aplikatif adalah proses mencari sesuatu atau penelitian yang langsung diterapkan; sedangkan metode eksploratif dalam penelitian ini mencari seluruh fungsi pada objek teliti. Kemudian aspek kreatifitas adalah pendekatan penelitian yang menjalakan seluruh fungsi objek teliti dengan proses pembuatan aransemen musik tingkat dasar.

\section{Bahan atau Materi}

Subjek penelitian adalah para mahasiswa pada mata kuliah Aplikasi Komputer yang diselenggarakan pada setiap semester, baik semester ganjil maupun genap. Peneliti memberikan berbagai materi 
karya musik, kemudian materi tersebut diolah dengan menggunakan program musik komputer yang khusus untuk proses menulis notasi.

\section{Alat Bantu}

Alat untuk membantu dalam mengungkapkan permasalahan pada penelitian ini menggunakan perangkat komputer, alat tulis, dan dokumentasi baik untuk perekaman ataupun foto.

\section{Jalan Penelitian}

Penelitian ini menyelusuri dari permasalahan yang dihadapi dalam kegiatan proses belajar mengajar mata kuliah Aplikasi Komputer yang dilakukan oleh mahasiswa Jurusan Musik FSP ISI Yogyakarta. Pengamatan dilakukan secara langsung di lapangan pada waktu kegiatan belajar mengajar menggunakan program komputer untuk mengaransemen musik.

4. Variabel

Variabel yang akan dipelajari diantaranya mahasiswa mata kuliah Aplikasi komputer, peran teknologi komputer, program aplikasi musik, dan langkahlangkah penggunaan teknologi komputasi untuk aransemen musik.

\section{Prosedur Pelaksanaan}

Penelitian ini secara kronologis dapat dilakukan melalui beberapa tahapan yaitu studi lapangan (observasi), studi pustaka, dan analisis data. Penelitian studi lapangan dilakukan untuk mendapatkan data-data tentang objek yang diteliti melalui observasi, wawancara dengan mengajukan pertanyaan-pertanyaan kepada nara sumber atau informan, dan perekaman. Observasi ditujukan kepada mahasiswa yang mengikuti kuliah Aplikasi Komputer di Jurusan Musik FSP ISI Yogyakarta. Selanjutnya untuk memperoleh data-data yang tidak dapat dilakukan melelui observasi, maka dilakukan wawancara langsung kepada mahasiswa, kemudian untuk mendukung kepentingan dalam pembahasan dilakukan perekaman secara audio visual pada pelaksanaan lomba paduan suara tersebut.

6. Analisis Data

Adapun data-data yang terkumpul dari hasil studi lapangan dan studi pustaka dianalisis secara kualitatif. Data tersebut dikelompokan sesuai dengan permasalahan yang dihadapi. Selanjutnya data tersebut disusun dalam kategori-kategori tertentu untuk mengacu pada pokok-pokok bahasan yang teleh ditentukan dalam penelitian.

\section{Pembahasan}

Proses penenlitian yang saat ini berjalan masih dalam tahapan pengenalan dan penjelajahan pada program komputer khusus untuk penulisan musik. Program komputer untuk penulisan musik menggunakan salah satu produksi dari Avid korporasi, yaitu Sibelius versi 7. Pemilihan program komputer tersebut memiliki fitur atau fungsi yang lebih mudah digunakan bagi pengguna tingkat awam hingga profesional. Adapun beberapa tahapan pada proses penelitian yang dilakukan melalui sebuah perkuliahan Aplikasi Komputer Musik yang diselenggarakan di Program Studi Seni Musik FSP ISI Yogyakarta. Empat tahapan dalam studi kasus menggunakan program komputer penulisan musik untuk pembelajaran aransemen musik, yaitu instalasi dan kelengkapannya, pengenalan fasilitas program komputer, menjalankan latihan dasar terdiri dari latihan praktik yang dilakukan oleh siswa, dan Tahap IV tahapan aransemen musik dasar.

\section{Instalasi dan Kelengkapannya}


Tahap awal yang perlu dilakukan dalam membuat sebuah aransemen musik menggunakan teknologi komputer melalui program musik komputer yaitu proses instalasi dan pengenalan perlengkapan yang harus dipersiapkan. Proses instalasi program musik komputer merupakan langkah awal bila alat komputer belum memiliki. Pada tahap ini partisipan melakukan kegiatan proses instal atau memasukkan program komputer musik ke dalam alat komputer. Partisipan menggunakan media komputer jinjing yakni laptop. Sebelum proses instalasi muncul berbagai permasalahan yaitu kompatiiltas dari media komputer, karena program komputer musik yang digunakan merupakan program komputer yang membutuhkan spesifikasi tertentu. Program komputer musik yang digunakan harus memiliki standar minimal dan program komputer musik Sibelius versi 7 dapat digunakan pada komputer berbasis sistem operasi windows dan machintos.

Sistem operasi Windows membutuhkan 64-bit Windows 7 (SP1 atau yang terakhir), Windows 8.1 (bukan versi Windows RT) or Windows 10, 1+ GB RAM, 1 GB kapasitas data hard disk untuk program musik komputer, DVD-ROM (hanya untuk Media Pack), dan membutuhkan koneksi internet untuk kativasi maupun mengunduh data. Bila user menggunakan Sounds library maka membutuhkan minimal kapasitas RAM 4+ GB, kapasitas penyimpanan data pada had disk 36 GB (SSD lebih baik), dan sistem komponen kartu suara standart kompetibel ASIO.

Sistem operasi Mac membutuhkan tipe sistem operasi Mac OS X 10.9 atau 10.10, 1+ GB dari RAM, Sibelius sendiri membutuhkan kapasitas tempat pada hard disk 1 GB; Sounds library Sibelius membutuhkan kapasitas hard disk 36 GB (instalasi tambahan), DVD-ROM (hanya untuk Media Pack), dan membutuhkan koneksi internet untuk kativasi maupun mengunduh data.

Partisipan mempersiapkan perangkat komputer dengan tipe komputer mobile atau komputer jinjing yang biasa disebut juga laptop. Kondisi perangkat peserta partisipan juga berbeda-beda ada yang memiliki sesuai dengan spesifikasi minimal yang dianjurkan juga terdapat spesifikasi di bawah yang disyarakat. Dengan kondisi tersebut maka perserta partisipan ada menggunakan progam musik komputer dengan versi di bawah yang di anjurkan. Sebagai contoh menggunakan program musik komputer Sibelius 6. Program musik komputer untuk menulis notasi Sibelius 6 atau versi sebelumnya tidak terdapat jauh perbedaan pada sistem penggunaanya dengan Sibelius 7, hanya beberapa menu dan tambahan yang terdapat versi terbaru tidak terdapat pada versi sebelumnya. Partisipan setelah mempersiapkan laptop, kemudian proses mengintal atau memasukan program musik komputer pada laptop. Pada proses ini partisipan sudah tidak kesulitan, karena cara instalasi sudah disusun secara mudah dan otomatis oleh pembuat progam musik komputer tersebut. Berikut suasana paparan dalam proses instalasi dan persiapan perangkat komputer.

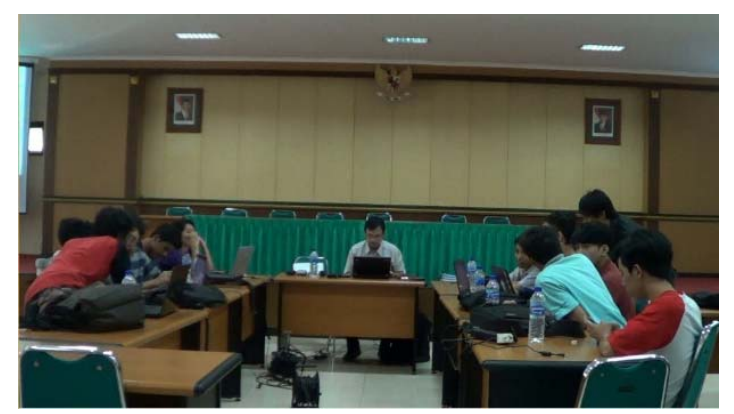

Gambar 5.1 Suasana Proses Instalasi Sibelius 7

(Foto: Agung, 2015)

Perlu diketahui bahwa menggunakan perangkat komputer dalam bentuk laptop dibutuhkan sebuah perangkat tambahan 
yang penting yaitu Keypad. Fungsi Keypad sangat penting, karena dengan Keypad eksternal untuk mengoperasikan menu keypad pada progam musik komputer Sibelius. Apabila menggunkan perangkat komputer desktop atau komputer pribadi dalam bentuk PC, maka tidak perlu tambahan Keypad, karena Keypad sudah ada pada keyboar standar PC. Komputer laptop juga ada fungsi Keypad pada keyboard-nya tetapi akan sangat mengganggu dalam proses menulis teks. Berikut bentuk Keypad eksternal bila menggunakan perangkat laptop.

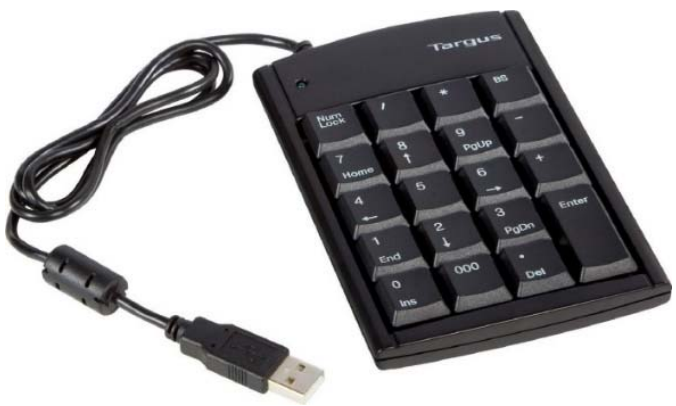

Gambar 5.2 Keypad atau Numlock (www.amazon.com/Targus-PAUK10U-Ultra-Ke Black/dp/B00008NG7N, Okt. 2015)

Proses instalasi program musik komputer Sibelius 7, sebagai berikut:

- Membuka Windows Explorer

- Mencari file Setup.exe dan klik 2x

- Ikuti proses instalasi dan kemudian aktivasi menggunakan koneksi internet

\section{Pengenalan Fasilitas Program Musik Komputer "Sibelius"}

Proses pengenalan program musik komputer Sibelius versi 7 pada partisipan dipaparkan secara detil dengan beberapa langkah. Hal ini penting agar partisipan tidak kebingungan dalam mengawali menggunakan program musik komputer tersebut.

\section{Menjalankan Latihan Dasar}

Proses latihan awal menggunakan program musik komputer Sibelius, memang dari hasil pengamatan sejumlah partisipan dengan tingkatan mengetahui tingkat dasar dan tingkat menengah. Sesuai dengan pengamatan, maka proses latihan dasar Sibelius harus diterapkan dengan beberapa kelompok latihan dasar, yaitu kelompok latihan dasar 1, kelompok latihan dasar 2, kelompok latihan dasar 3, dan kelompok latihan dasar 4 .

Kelompok latihan dasar ke-1 mengenalkan menu-menu dan fungsi dari program musik Sibelius seperti, bagaimana membuka skor, memperkenalkan papan menu, menjelaskan bagaimana untuk menavigasi di sekitar skor menggunakan kedua panel Navigator dan berbagai keyboard dan mouse, membuat pilihan, dan copy dan paste. Menggunakan susunan lagu rakyat Scarborough Fair, bagaimana untuk mengedit dan catatan masukan menggunakan mouse, komputer dan keyboard MIDI, dan bagaimana masukan lirik. Partispan diperkenalkan dengan pemutaran, dan menulis teks serta memberi tanda dinamika pada.

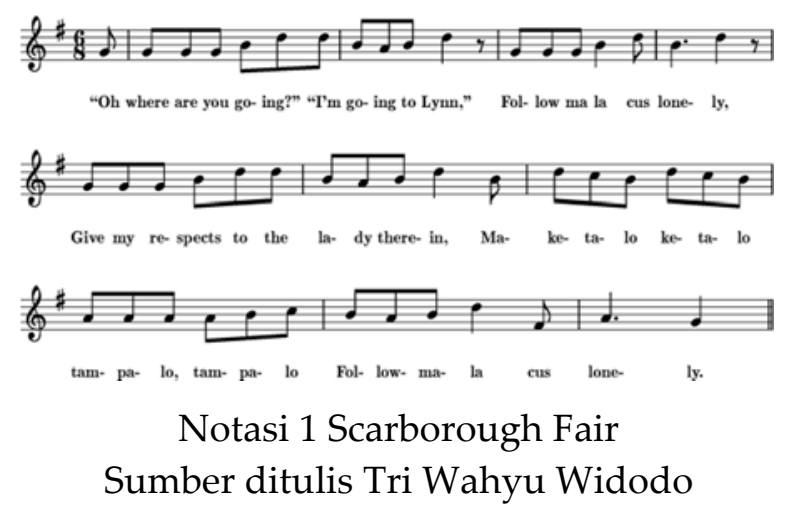

Kelompok latihan dasar ke-2 partisipan akan belajar untuk menciptakan kutipan dari Elgar String Quartet di E minor, Op. 83 dengan cara menulis ulang pada program Sibelius sehingga akan belajar cara membuat kunci dan perubahan tanda kunci, masukan tulisan-tulisan penting pada Score termasuk tuplets, dan mengeksplorasi 
berbagai jenis tanda - termasuk artikulasi, garis, legato, Slur dan teks - yang biasa digunakan untuk menandai skor. Partisipan juga akan diperkenalkan membuka part musik secara dinamis dan mengekspor grafis dari Sibelius. Berikut potongan notasi violin satu dari karya Edward Elgar pada String Quartet di E minor, Op. 83.

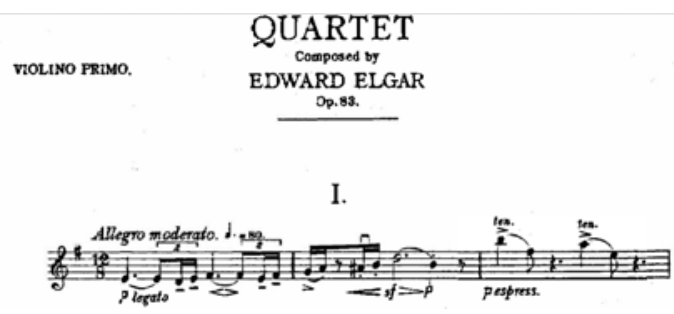

Notasi 2 Violin Primo String Quartet di E minor, Op. 83 oleh Edward Elgar

Kelompok latihan dasar ke-3 ini mengajarkan dasar-dasar menulis untuk keyboard, gitar dan drum, bersama-sama pengenalan menulis simbol-simbol akord dan pengulangan struktur musik (pengulangan kamar 1 dan pengulangan kamar 2, dan DS al Coda). Kemudian partisipan juga akan mengeksplorasi pengaturan pemutaran karya musik menggunakan panel Mixer dan belajar bagaimana menggunakan panel Idea pada Sibelius untuk menyimpan dan menggunakan kembali potongan musik.

Kelompok latihan dasar ke-4 ini sangat berguna bagi partisipan berencana untuk membuat bahan pembelajaran bagi siswa atau untuk mengajar musik dengan Sibelius di kelas dan mempelajari beberapa teknik yang lebih canggih untuk meletakkan dan format musik. Dalam latihan dara ini akan membuat lembar kerja tangganada, menyembunyikan tongkat kosong, mengubah font teks, dan banyak lagi.

\section{Aransemen Musik Dasar}

Pada tahap akhir partisipan dapat melakukan proses aransemen dan orkestrasi musik dengan memberikan sebuah materi musik dengan judul Scarborough Fair. Aransemen musik dalam bentuk format band dan string ensambel.

\section{Penutup}

Teknologi komputer sampai saat ini telah memiliki tingkat kecesrdasan buatan yang sangat pesat seiring dengan perkembangan elektroniknya. Tingkat kecerdasan elektronik yang tinggi; permasalahan dan kebutuhan manusia yang pada awalnya secara manual, maka dengan menggunakan teknologi komputer dapat diatasi. Melalui teknologi komputer yang menggunakan perangkat lunak atau program komputer musik, seorang musisi mendapat kemudahan secara teknis untuk mengeluarkan ide-ide kreatif. Program-program komputer yang dikhususkan untuk bidang seni musik telah banyak dibuat oleh berbagai produsen program komputer. Salah satu progam komputer untuk musik yaitu Sibelius versi 7. Melalui program komputer tersebut tidak hanya seorang musisi tetapi program tersebut dapat bermanfat untuk membuat suatu karya baik komposisi musik baru maupun aransemen musik.

Program komputer Sibelius merupakan progam komputer untuk musik yang dikhususkan untuk tulis menulis notasi. Melalui progam komputer tersebut maka seorang pengguna komputer tidak hanya menulis tetapi juga dapat membuat karya musik baru atau aransemen musik.

Saran

Penelitian yang akan dilakukan ini memberikan pengetahuan secara teknis maupun metodologis dalam membuat suatu tulisan musik baik baru maupun yang sudah ada. Sehingga peserta teliti memerlukan kegiatan rutin dalam menggunakan program komputer tersebut. Saran yang lebih penting dalam penerapan dari hasil 
penelitian ini yaitu diperlukan kegiatan yang rutin untuk menggunakan program komputer musik Sibelius. Adapun saran yang lain yakni dibutuhkan sebuah laboratorium komputer musik yang representatif dan memedai. Hal tersebut menjadi kendala sampai saat ini dalam menyelesaikan penelitian peran teknologi komputer untuk proses aransemen musik.

\section{Referensi}

Bono, Edward de. 1996. Serious Creativity: Using Power of Lateral Thinking to Create New Ideas, London: Harper Collin Business.

Buick, Peter dan Lennard, Vic. 1995. Music Technology: Reference book, Unitet Kingdom: PC Publishing.

Dey, Ian. 1993. Qualitative Data Analysis, London dan New York: Routledge. Djanali, Supeno (Ketua Tim). 2005.

Tim Pakar Seni. 2007. Paradigma Baru Pendidikan Tinggi Seni di Indonesia, Jakarta: Direktorat Pembinaan Akademik dan Kemahasiswaan, Ditjen Dikti, Depdiknas.

Djanali, Supeno (Ketua Tim). 2005. RambuRambu Akademik Pendidikan Tinggi Seni Di Indonesia, Jakarta: Direktorat Pembinaan Akademik dan Kemahasiswaan, Ditjen Dikti, Depdiknas.
Kaelan. 2005. Metode Penelitian Kualitatif Bidang Filsafat. Yogyakarta: Penerbit "Paradigma".

Manning, Peter. 1993. Electronic and Computer Music. Ed. $2^{\text {nd }}$., New York: Oxford University Press. Inc.

Pannen, Paulina. 2005. Pendidikan Sebagai Sistem, Program PEKERTI Buku 1.02, Jakarta: PAU Untuk Peningkatan dan Pengembangan Aktivitas Instruksional, Ditjen Dikti, Depdiknas.

Sacher, Jack dan James Eversole. 1977. The Art of Sound: An Introduction to Music, $2^{\text {nd }}$ Edition, Englewood Cliffs, New Jersey: Prentice-Hall, Inc.

Spreadbury, Daniel dan Finn, Ben \& Jonathan. 2003. Sibelius 3: User Guide, London: The Old Toy Factory.

Suparman. 1997. Komputer Pribadi Menyongsong Abad 21: Hardware, software, Barinware dan Internet, Jakarta: PT Dinastindo Adiperkasa Internasional

Williams, Robin dan Cummings, Steve.1994. Istilah Mutakhir Dunia Komputer, Jakarta: PT Dinastindo Adiperkasa Internasional.

Zainuddin, M. dan Susy Puspitasari. 2005. Strategi Peningkatan Kualitas Pendidikan Tinggi I, Program PEKERTI Buku 1.01, Jakarta: PAU Untuk Peningkatan dan Pengembangan Aktivitas Instruksional, Ditjen Dikti, Depdiknas. 